Journal of Organometallic Chemistry, 358 (1988) 545-562

Elsevier Sequoia S.A., Lausanne - Printed in The Netherlands

\title{
Organopalladium complexes with bidentate phosphorus and nitrogen containing ligands
}

\author{
Wim de Graaf, Sjoerd Harder, Jaap Boersma *, Gerard van Koten, \\ University of Utrecht, Laboratory of Organic Chemistry, Department of Metal-Mediated Synthesis, \\ Padualaan 8, 3584 CH Utrecht (The Netherlands)
}

and Jan A. Kanters

University of Utrecht, Laboratory for Crystal and Structural Chemistry, Padualaan 8, $3584 \mathrm{CH}$ Utrecht (The Netherlands)

(Received April 29th, 1988)

\begin{abstract}
Organopalladium complexes containing the potentially $\mathbf{P}, \mathrm{N}$-bidentate ligands $o$-diphenylphosphino- $N, N$-dimethylbenzylamine (PN) and $o$-diphenylphosphino- $\alpha$ methyl- $N, N$-dimethylbenzylamine ( $\left.\mathrm{PN}^{\star}\right)$ have been studied. The palladium( 0 ) complexes $\mathbf{P d}(\mathbf{P}-\mathbf{N})_{3}\left(\mathbf{P}-\mathbf{N}=\mathbf{P N}\right.$ or $\left.\mathbf{P N}^{\star}\right)$ have been prepared; the ligands coordinate to the metal primarily through phosphorus, with the amine function coordinating not at all or only very weakly. Oxidative addition of several organic halides to these palladium( 0 ) complexes afforded the corresponding monoorganopalladium(II) complexes $\mathbf{P d}(\mathbf{R})(\mathbf{X})(\mathbf{P}-\mathbf{N})$ in which the donor ligands are $\mathbf{P}, \mathbf{N}$-bidentate coordinated. In solution the divalent species possess a Pd-N bond, and even in the presence of either free ligand, $\mathrm{CO}$ or $\mathrm{X}^{-}$there is no evidence for dissociation or displacement of the amine function from the metal centre. Complexes $\mathrm{PdMe}_{2}(\mathrm{P}-\mathrm{N})$ have been prepared from the corresponding dihalopalladium complexes by treatment with MeLi. Reaction of these dimethylpalladium species with the electrophiles MeI, $\mathrm{MeBr}$ and $\mathrm{PhCH}_{2} \mathrm{Br}$ resulted in replacement of one methyl group by halogen. The structures of $\mathrm{Pd}(\mathrm{Me})(\mathrm{Br})(\mathrm{PN})$ and $\mathrm{Pd}\left(\mathrm{C} \equiv \mathrm{CSiMe}_{3}\right)(\mathrm{Br})(\mathrm{PN})$ have been determined by $\mathrm{X}$-ray diffraction studies. $\mathrm{Pd}(\mathrm{Me})(\mathrm{Br})(\mathrm{PN})$ crystallizes in space group $C c$ with $a$ 8.379(8), $b 17.363(7)$ and $c 14.818(6) \AA, \beta 99.34(5)^{\circ}$, and $Z=4$; the structure was refined to $R_{\mathrm{f}}=0.030$. $\mathrm{Pd}\left(\mathrm{C} \equiv \mathrm{CSiMe} \mathrm{C}_{3}\right)(\mathrm{Br})(\mathrm{PN})$ crystallizes in space group $P 2_{1} / c$ with $a 13.478(3), b 10.848(2)$ and $c 19.212(3) \AA, \beta 102.59(2)^{\circ}$, and $Z=4$; the structure was refined to $\boldsymbol{R}_{\mathrm{f}}=\mathbf{0 . 0 3 8}$. Both complexes have a square planar configuration around palladium, with the organic group $\left(\mathrm{Me}, \mathrm{C} \equiv \mathrm{CSiMe}_{3}\right)$ trans to the amine function and the six-membered chelate ring in a boat conformation.
\end{abstract}

\footnotetext{
* Author to whom correspondence should be addressed.
} 


\section{Introduction}

Many chiral ligands used in palladium- and nickel-catalyzed asymmetric crosscoupling reactions (eq. 1) contain both a phosphorus and a nitrogen donor atom [1].

$$
\mathbf{R m}+\mathbf{R}^{\prime} \mathbf{X} \stackrel{\mathrm{LPdCl}_{2}, \mathrm{LNiCl}_{2}}{\longrightarrow} \mathbf{R R}^{\prime}+\mathbf{m X}
$$

$(\mathrm{m}=\mathrm{Li}, \mathrm{MgX}, \mathrm{ZnX})$

Two examples of such ligands are $\mathrm{Me}_{2} \mathrm{NCHRCH}_{2} \mathrm{PPh}_{2}$ (1) derived from $\alpha$ aminoacids, and (R)-N,N-dimethyl-1-[(S)-2-(diphenylphosphino)ferrocenyl]ethylamine, $(R)-(S)$-PPFA (2) derived from ferrocene.<smiles>[R]C(C[PH])CN(C)c1ccccc1</smiles>

1

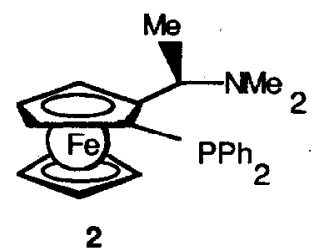

2

Because of their relevance to catalysis, studies of the reactions of isolated organopalladium complexes possessing $\mathbf{P}, \mathrm{N}$-bidentate ligands would be very interesting, but, surprisingly, little work seems to have been carried out in this area. One particular aspect of such $\mathrm{P}, \mathrm{N}$-ligands is that the combination of a hard and a soft donor atom site should not only allow formation of bidentate complexes but might also possibly lead to species having a monodentate P-bonded ligand whose amine function is uncoordinated as a result of dissociation or displacement. Kumada et al. considered this latter feature to be responsible for the stereocontrol exhibited in the reaction of vinyl bromide with secondary Grignard reagents, catalyzed by nickel and palladium complexes of ligands 1 and 2 [1].

In the coordination chemistry of P,N-bidentate ligands the nature of the Pd-N bond will be strongly influenced by the oxidation state of palladium. When the palladium centre is zerovalent, the coordination of nitrogen to palladium is not favourable; this is reflected in the molecular structure of $\mathrm{Pd}\left[\mathrm{N}\left(\mathrm{CH}_{2} \mathrm{CH}_{2} \mathrm{PPh}_{2}\right)_{3}\right]$, reported by Orlandi et al. [2]. In palladium(II) complexes Pd-N coordination is well documented [3], but the smaller trans-influence of nitrogen relative to phosphorus [4] implies that Pd-N coordination should be weaker than Pd-P coordination. For the formation of palladium(II) complexes with such ligands two main types of bonding are likely, viz. $\mathrm{P}, \mathrm{N}$-bidentate coordination by one ligand or monodentate $P, P^{\prime}$ coordination by two ligands.

Another aspect of P,N-bidentate ligands is that the hard amine site should help stabilize higher oxidation states, and so their use might facilitate reactions proceeding via organopalladium(IV) intermediates and, under suitable circumstances, might lead to isolable organopalladium(IV) species.

This present work describes the synthesis and coordination behaviour of some new palladium compounds with the $\mathrm{P}, \mathrm{N}$-bidentate ligands o-diphenylphosphino$N, N$-dimethylbenzylamine (3) (prepared earlier by Rauchfuss et al. [5]) and its $(R)-\alpha-$ Me homologue $3^{\star}$. In contrast to 3 , the latter ligand has the advantage that Pd-N coordination can be easily detected by ${ }^{1} \mathrm{H}$ NMR spectroscopy. When the $\mathrm{NMe}_{2}$ group of $3^{\star}$ is coordinated, inversion at the amine donor site is inhibited, and 
this renders the methyl groups on nitrogen diastereotopic. However, if dissociation of the $\mathrm{NMe}_{2}$ occurs and if the lifetime of the uncoordinated amine donor site is long on the NMR timescale, then because there is a low inversion barrier for tertiary amines the methyl groups on nitrogen are homotopic.<smiles>CN(Cc1ccccc1P)c1ccccc1</smiles><smiles>CC(C)c1ccc([N+]#N)cc1-c1ccccc1</smiles>

\section{Results}

\section{Palladium(0) complexes}

The palladium(0) complexes $\operatorname{Pd}(\mathrm{PN})_{3}(4)$ and $\operatorname{Pd}\left(\mathrm{PN}^{\star}\right)_{3}\left(4^{\star}\right)$ were prepared in ca. $40 \%$ yield (eq. 2 ) by hydrazine hydrate reduction of $\mathrm{PdCl}_{2}$ in the presence of an excess of the ligand $\mathbf{P}-\mathbf{N}\left(\mathrm{P}-\mathbf{N}=\mathbf{P N}\right.$ or $\left.\mathrm{PN}^{\star}\right)$ in dimethyl sulfoxide.

$$
\begin{aligned}
& \mathrm{PdCl}_{2}+>4 \mathrm{P}-\mathrm{N} \frac{\mathrm{N}_{2} \mathrm{H}_{4} \cdot \mathrm{H}_{2} \mathrm{O}}{\mathrm{DMSO}} \mathrm{Pd}(\mathrm{P}-\mathrm{N})_{3} \\
&(4: \mathrm{P}-\mathrm{N}=\mathrm{PN}(40 \%) ; \\
&\left.4^{\star}: \mathrm{P}-\mathrm{N}=\mathrm{PN}^{\star}(40 \%)\right)
\end{aligned}
$$

These novel complexes were isolated as yellow air-sensitive solids. They should be stored in an inert atmosphere at $-30^{\circ} \mathrm{C}$ or below. They are readily soluble in benzene, but the solutions obtained are not stable at room temperature and slowly turn red.

Although satisfactory elemental analyses $(\mathrm{C}, \mathrm{H})$ were obtained for 4 , the $1 / 3$ palladium/ligand ratio was more accurately obtained after oxidative addition reactions with $\mathrm{Me}_{3} \mathrm{SiC}=\mathrm{CBr}$ (vide infra) because the contribution of palladium to the molecular weight of 4 is low. When first prepared, the sample complex $4^{\star}$ obtained incorporates two equivalents of dimethyl sulfoxide, which cannot be removed in vacuo $\left(100^{\circ} \mathrm{C} / 0.01 \mathrm{mmHg}\right)$. Samples of $4^{\star}$ free of dimethyl sulfoxide are obtained by recrystallization from benzene/pentane, and these afford ${ }^{1} H$ NMR spectra identical, except for the absence of dimethyl sulfoxide signals, to those of the original product. Because loss of material on recrystallisation was significant, all further studies were carried out with the non-recrystallized material.

The ${ }^{1} \mathrm{H}$ NMR spectra of the complexes 4 and $4^{\star}$ in $C_{6} D_{6}$ at room temperature show only one pattern for the $\mathrm{PN}$ and $\mathrm{PN}^{\star}$ ligands (see Table 1), with the dimethylamino groups providing sharp singlets at $\delta 1.87$ and $1.95 \mathrm{ppm}$, respectively. Since these values do not differ much from those found for the free ligands $(\delta 1.94$ ppm for both 3 and $3^{\star}$ ) it can be deduced that the amine function is not bonding to the metal centre on the NMR timescale. Lowering the temperature of a solution of $4^{\star}$ in toluene- $d_{8}$ to $-80^{\circ} \mathrm{C}$ caused some broadening, but no splitting of the $\mathrm{NMe}_{2}$ signals.

The ${ }^{31} \mathrm{P}$ NMR spectrum of $4^{\star}$ in toluene- $d_{8}$ at $-40^{\circ} \mathrm{C}$ afforded two singlets; the main one at $+17.3 \mathrm{ppm}$ and a smaller one at $-16.7 \mathrm{ppm}$ (relative to $\mathrm{H}_{3} \mathrm{PO}_{4}$ ). The 
Table 1

${ }^{1} \mathrm{H}$ NMR data for $\mathrm{PN}$ and $\mathrm{PN}^{\star}$ palladium complexes ${ }^{a}$

\begin{tabular}{llllll}
\hline Compound & PdMe & $\alpha-\mathrm{Me}^{h}$ & $\mathrm{NMe}_{2}$ & $\mathrm{CH}_{2} / \mathrm{CH}$ & aryl \\
\hline $\mathbf{3}^{b}$ & & $1.94 \mathrm{~s}$ & $3.68 \mathrm{~s}$ & $6.8-7.6 \mathrm{~m}$ \\
$\mathbf{4}^{b}$ & & $1.87 \mathrm{~s}$ & $3.73 \mathrm{~s}$ & $6.7-8.0 \mathrm{~m}$ \\
$5^{c}$ & & $2.9 \mathrm{br} \mathrm{s}$ & $3.4 \mathrm{br} \mathrm{s}$ & $7.2-7.6 \mathrm{~m}$ \\
$\mathbf{6 a}^{c}$ & $0.78 \mathrm{~d}^{d}$ & & $2.69 \mathrm{br} \mathrm{s}$ & $3.37 \mathrm{br} \mathrm{s}$ & $6.65-7.70 \mathrm{~m}$ \\
$\mathbf{6 b}^{c}$ & $0.65 \mathrm{~d}^{c}$ & & $2.52 \mathrm{br} \mathrm{s}$ & $3.25 \mathrm{br} \mathrm{s}$ & $6.65-7.55 \mathrm{~m}$ \\
$\mathbf{6 c}^{c}$ & & & $2.40 \mathrm{br} \mathrm{s}$ & $2.70 \mathrm{br} \mathrm{s}$ & $6.45-7.65 \mathrm{~m}$ \\
$7^{b}$ & $0.82 \mathrm{~d}, 0.86 \mathrm{~d}^{f}$ & & $2.23 \mathrm{~s}$ & $3.05 \mathrm{br} \mathrm{s}$ & $6.6-7.7 \mathrm{~m}$ \\
$\mathbf{3}^{\star b}$ & & $1.20 \mathrm{~d}$ & $1.94 \mathrm{~s}$ & $4.28 \mathrm{q}$ & $7.2-7.6 \mathrm{~m}$ \\
$\mathbf{4}^{\star b}$ & & $1.28 \mathrm{~d}$ & $1.95 \mathrm{~s}$ & $5.0 \mathrm{br} \mathrm{s}$ & $6.8-7.8 \mathrm{~m}$ \\
$\mathbf{5}^{\star c}$ & & $1.35 \mathrm{~d}$ & $2.84 / 3.20 \mathrm{br} \mathrm{s}$ & $3.30 \mathrm{brq}$ & $7.2-8.1 \mathrm{~m}$ \\
$\mathbf{6 b}^{\star c}$ & $0.67 \mathrm{~d}^{\mathrm{g}}$ & $1.23 \mathrm{~d}$ & $2.55 / 2.95 \mathrm{br} \mathrm{s}$ & $3.33 \mathrm{br} \mathrm{q}$ & $6.8-7.8 \mathrm{~m}$ \\
$\mathbf{6 c}^{c}$ & & $1.28 \mathrm{~d}$ & $2.58 / 3.09 \mathrm{br} \mathrm{s}$ & $3.39 \mathrm{br} \mathrm{q}$ & $6.8-8.3 \mathrm{~m}$ \\
$\mathbf{7}^{\star b}$ & $0.82 \mathrm{~d}, 0.86 \mathrm{~d}^{f}$ & $1.22 \mathrm{~d}$ & $2.24 / 2.44 \mathrm{br} \mathrm{s}$ & $3.05 \mathrm{br} \mathrm{q}$ & $6.6-7.9 \mathrm{~m}$ \\
\hline
\end{tabular}

${ }_{a}^{a} 80 \mathrm{MHz}$, in ppm relative to internal $\mathrm{SiMe}_{4}{ }^{b}$ In $\mathrm{C}_{6} \mathrm{H}_{6 .}{ }^{c}$ In $\mathrm{CDCl}_{3 .}{ }^{d{ }^{3} J(\mathrm{P}, \mathrm{H})} 5.1 \mathrm{~Hz} .{ }^{{ }^{3} J(\mathrm{P}, \mathrm{H})} 3.7$ Hz. ${ }^{f 3} J(\mathrm{P}, \mathrm{H}) 6.7$ and $8.7 \mathrm{~Hz} .{ }^{3} J(\mathrm{P}, \mathrm{H}) 3.4 \mathrm{~Hz} .{ }^{h 3} J(\mathrm{H}, \mathrm{H}) 6.6-7.2 \mathrm{~Hz}$.

latter, the proportion of which varied (5-15\%) from batch to batch, is assigned on the basis of its chemical shift to free ligand impurity. When this solution is warmed to room temperature the peaks coalesce to afford a single broad signal, and it can therefore be concluded that the free $\mathrm{PN}^{\star}$ ligand is undergoing exchange with the coordinated ligands in $\mathrm{Pd}\left(\mathrm{PN}^{\star}\right)_{3}$.

To study the possibility of palladium-nitrogen coordination in $4^{\star}$, its ${ }^{13} \mathrm{C}$ NMR spectra in toluene- $d_{8}$ were recorded at various temperatures. At room temperature only one $\mathrm{PN}^{\star}$ ligand pattern was observed. Lowering the temperature to $-60^{\circ} \mathrm{C}$ caused this to split into two sets of signals with the minor one again being attributed to free $\mathrm{PN}^{\star}$. At this temperature the ${ }^{13} \mathrm{C}$ signal of the $\mathrm{NMe}_{2}$ group of the coordinated ligand was a singlet at $\delta 43.48 \mathrm{ppm}$ (cf. free ligand at $\delta 41.32 \mathrm{ppm}$ ), indicating that there is no significant coordination of the amine centre to palladium.

The low temperature ${ }^{31} \mathrm{P}$ and ${ }^{13} \mathrm{C}$ NMR spectra show no signals that can be interpreted as arising from either $\mathrm{Pd}\left(\mathrm{PN}^{\star}\right)_{4}$ through association, or $\operatorname{Pd}\left(\mathrm{PN}^{\star}\right)_{2}$, through dissociation of a ligand.

\section{Organopalladium(II) complexes}

Organopalladium(II) complexes with ligands 3 and $3^{\star}$ were prepared by three routes, i.e. oxidative addition to palladium( 0 ) complexes, alkylation of dihalopalladium complexes and reactions of the dimethylpalladium complexes with electrophiles.

\section{Oxidative additions}

Reaction of the organic halides $\mathrm{MeI}, \mathrm{MeBr}$ and $\mathrm{Me}_{3} \mathrm{SiC} \equiv \mathrm{CBr}$ with the palladium(0) complex 4 and of $\mathrm{Me}_{3} \mathrm{SiC} \equiv \mathrm{CBr}$ with $4^{\star}$ afforded the oxidative addition products $6 a-6 c$ and $6 c^{\star}$, respectively (eq. 3 ). Although the preparation of monoorganopalladium complexes $\operatorname{Pd}(R)(X)(P-N)$ by oxidative addition of $R X$ to the palladium( 0 ) complexes 4 and $4^{\star}$ seems to be very general, the reactions of MeI and $\mathrm{MeBr}$ were complicated by quaternarization of the free ligand. To get complexes $6 a$ and $6 \mathrm{~b}$ in purer form it is better to make them from $\operatorname{PdMe}_{2}(P-N), 7$ and 
$7^{\star}$, by replacement of a methyl group by reaction with $\mathrm{PhCH}_{2} \mathrm{Br}$ or $\mathrm{MeI}$ (eq. 5) (vide infra).

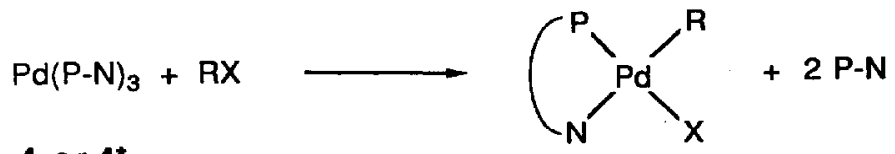

4 or $4^{*}$

$$
\begin{array}{rlr}
6 \text { a } & P-N=P N ; R=M e, X=1 & (80 \%) \\
\text { b } P-N=P N ; R=M e, X=B r & (80 \%) \\
\text { c } P-N=P N ; R=M e_{3} S i C \equiv C, X=B r & (70 \%) \\
\text { C }^{*} \mathrm{P}-\mathrm{N}=\mathrm{PN} * \mathrm{R}=\mathrm{Me} \mathrm{e}_{3} \mathrm{SiC}=\mathrm{C}, \mathrm{X}=\mathrm{Br} & (80 \%)
\end{array}
$$

Satisfactory elemental analyses $(\mathrm{C}, \mathrm{H})$ were obtained for $6 \mathrm{c}$. The ${ }^{1} \mathrm{H}$ NMR spectra of $6 \mathrm{a}$ and $\mathrm{6b}$ show the resonances of the methyl groups on palladium as doublets at $\delta 0.78 \mathrm{ppm}\left({ }^{3} J(\mathrm{P}, \mathrm{H}) 4.5 \mathrm{~Hz}\right)$ and at $\delta 0.65 \mathrm{ppm}\left({ }^{3} J(\mathrm{P}, \mathrm{H}) 3.7 \mathrm{~Hz}\right)$, respectively. In the ${ }^{1} \mathrm{H}$ NMR spectrum $(80 \mathrm{MHz}, \mathrm{RT})$ of complex $6 c^{\star}$, and the other palladium(II) ( $\mathrm{PN}^{\star}$ ) complexes $5 \mathbf{a}^{\star}, \mathbf{6 b}^{\star}$ and $7^{\star}$, the dimethylamino group gives two broad signals. In the range -63 to $+68^{\circ} \mathrm{C}$ these two signals from a solution of $6 \mathrm{~b}^{\star}$ in $\mathrm{CDCl}_{3}$ become sharper as the temperature was raised; palladium-nitrogen bond dissociation is therefore not occurring significantly on the NMR time scale, and the observed line broadening at lower temperature can probably be attributed to restricted puckering movements of the six-membered chelate ring.

The reaction of $\mathrm{Me}_{3} \mathrm{SiC} \equiv \mathrm{CBr}$ with $4^{\star}$, which gives $6 c^{\star}$, was studied by ${ }^{1} \mathrm{H}$ and ${ }^{31} \mathrm{P}$ NMR spectroscopy at room temperature. Immediately after addition of a slight excess of $\mathrm{Me}_{3} \mathrm{SiC} \equiv \mathrm{CBr}$ to $4^{\star}$ the signals $\left({ }^{1} \mathrm{H}\right.$ and ${ }^{31} \mathrm{P}$ ) of $6 c^{\star}$ and free $\mathrm{PN}{ }^{\star}$ were observed in the ratio of $1 / 2.0-2.3$. This value gives a $\mathrm{Pd} /$ ligand ratio for complex $4^{\star}$ of $1 / 3.0-3.3$. The small deviation from a $1 / 3$ ratio for $\operatorname{Pd}(\mathrm{PN})_{3}$ is probably attributable to free ligand impurity in this palladium(0) starting material. Remarkably, the ${ }^{1} \mathrm{H}$ NMR spectrum of complex $6 c^{\star}$ is not affected by the presence of free $\mathrm{PN}^{\star}$, and it can be inferred that the chelate bonding of $\mathrm{PN}^{\star}$ in this complex is much more favourable than formation of a species with two ligands bonded only through phosphorus. Moreover, treatment of a solution of $\mathbf{6 b}^{\star}$ with carbon monoxide (1 atm) did not lead to displacement of the amine function, and no insertion in the palladium-carbon bond was observed. The effect of free halide on the stability of the chelate ring was studied by introducing tetrabutylammonium bromide into a solution of $6^{\star}$ in $\mathrm{CDCl}_{3}$; no change in the ${ }^{1} \mathrm{H}$ NMR spectrum (80 $\mathrm{MHz}, \mathrm{RT}$ ) was observed.

It is not easy to determine the configuration (cis/trans) around palladium in these $\operatorname{Pd}(\mathrm{R})(\mathrm{X})(\mathrm{P}-\mathrm{N})$ complexes by spectroscopic methods. In the ${ }^{1} \mathrm{H}$ NMR spectra the ${ }^{3} \mathrm{~J}\left(\mathrm{P}, \mathrm{CH}_{3}\right)$ couplings for the cis and trans methyl groups are similar (for example 6.7 and $8.7 \mathrm{~Hz}$ in $\mathrm{PdMe}_{2}(\mathrm{PN}$ ) (7); vide infra). In the IR spectra the Pd-C stretching frequency of $483 \mathrm{~cm}^{-1}$ for $6 \mathrm{~b}$ is relatively low, and suggests the presence of a strong trans ligand (cf. cis-PdMe $\left(\mathrm{PPh}_{3}\right)_{2}: 529,482 \mathrm{~cm}^{-1} ; \mathrm{PdMe}_{2}$ (bipyridine): $534,522 \mathrm{~cm}^{-1}$ ) [6]. The Pd-Br stretching frequency is low, and almost no reference data are available. For these reasons the crystal structures of $6 b$ and $6 c$ were determined by single crystal $X$-ray diffraction. The results, described in detail below, show that these $\operatorname{Pd}(\mathbf{R})(\mathrm{X})(\mathrm{PN})$ complexes have the organic group (Me or $\mathrm{Me}_{3} \mathrm{SiC} \equiv \mathrm{C}$ ) situated cis relative to phosphorus, which is in accord with the trans-influence (see Discussion). 
Alkylation of dihalide complexes

The complexes $\mathrm{PdCl}_{2}(\mathrm{PN})(5 \mathrm{a}), \mathrm{PdCl}_{2}\left(\mathrm{PN}^{\star}\right)\left(5 \mathrm{a}^{\star}\right)$, and $\mathrm{PdBr}_{2}(\mathrm{PN})(5 \mathrm{~b})$ were readily prepared by the action of either $\mathrm{PN}$ or $\mathrm{PN}^{\star}$ on the corresponding $\mathrm{PdX}_{2}(\mathrm{MeCN})_{2}$ complexes. Attempts to prepare $\mathbf{6 d}$, the geometrical isomer of $\mathbf{6 b}$ (eq. 4), by treatment of $\mathrm{PdBr}_{2}(\mathrm{PN})$ (5b), with one equivalent of $\mathrm{MeLi}$ were unsuccessful. Substitution of the bromine trans to phosphorus was expected, as a consequence of the larger trans-effect of phosphines compared to amines [7], but these reactions provided only a small amount of $6 \mathbf{b}(5 \%)$ together with $\mathrm{PdMe}_{2}(\mathrm{PN})$ (45\%) and starting material $5 \mathrm{~b}(50 \%)$. The most likely explanation of this result is that complex $6 \mathrm{~d}$ is formed as an intermediate and rearranges to thermodynamically more stable $\mathbf{6 b}$.<smiles>Br[Te]1(Br)(Br)CCCN1</smiles>

5b

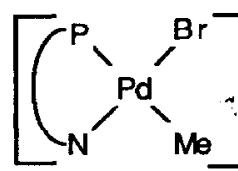

$6 d$<smiles>C[PH]1(Br)NCCP1</smiles>

$6 \mathrm{~b}$

Treatment of the dihalide complexes $5 \mathbf{a}$ (or $\mathbf{5 b}$ ) and $5 \mathbf{a}^{\star}$ with an excess of $\mathrm{MeLi}$ afforded $\mathrm{PdMe}_{2}(\mathrm{PN})(7)$ and $\mathrm{PdMe}_{2}\left(\mathrm{PN}^{\star}\right)\left(7^{\star}\right)$, respectively, which were isolated as cream-white air-stable solids. Their solutions in benzene are stable for a few hours

Table 2

Crystal data and data collection for 6 and $6 c$

\begin{tabular}{|c|c|c|}
\hline & $\mathbf{6 b}$ & $6 c$ \\
\hline $\begin{array}{l}\text { formula } \\
\text { crystal system }\end{array}$ & $\begin{array}{l}\mathrm{C}_{22} \mathrm{H}_{25} \mathrm{BrNPPd} \\
\text { monoclinic }\end{array}$ & $\begin{array}{l}\mathrm{C}_{26} \mathrm{H}_{31} \mathrm{BrNPPdSi} \\
\text { monoclinic }\end{array}$ \\
\hline$z$ & 4 & 4 \\
\hline space group & $C c$ & $P 2_{1} / c$ \\
\hline$a, \AA$ & $8.739(8)$ & $13.478(3)$ \\
\hline$b, \AA$ & $17.363(7)$ & $10.848(2)$ \\
\hline$c, \AA$ & $14.818(6)$ & $19.212(3)$ \\
\hline$\beta$, deg & $99.34(5)$ & $102.59(2)$ \\
\hline$V, \AA^{3}$ & $2219(2)$ & $2741.4(9)$ \\
\hline$\rho$ (calcd), $\mathrm{g} / \mathrm{cm}^{3}$ & 1.559 & 1.461 \\
\hline$\rho$ (measd), $\mathrm{g} / \mathrm{cm}^{3}$ & 1.568 & \\
\hline mol wt & 520.75 & 602.92 \\
\hline radiation, $\AA$ & $\mathrm{Cu}-K_{\alpha} 1.54184$ & $\mathbf{M o - K} K_{\alpha} 0.71073$ \\
\hline filter & $\mathbf{N i}$ & $\mathbf{Z r}$ \\
\hline scan method & $\omega-2 \theta$ & $\omega-2 \theta$ \\
\hline scan speed & variable & variable \\
\hline $2 \theta$, limit, deg & $0-140$ & $0-55$ \\
\hline temp. ${ }^{\circ} \mathrm{C}$ & 22 & 21 \\
\hline no of refl. & 4442 & 6271 \\
\hline refl. obsd., $I \geqslant 2.5 \sigma(I)$ & 2219 & 4099 \\
\hline abs coeff, $\mathrm{cm}^{-1}$ & 97.7 & 22.2 \\
\hline F000, electrons & 1040 & 1216 \\
\hline$R(F)^{a}$ & 0.030 & 0.038 \\
\hline$R(w F)^{a}$ & 0.036 & 0.034 \\
\hline
\end{tabular}


at room temperature, but upon longer standing metallic palladium slowly separates. In the ${ }^{1} \mathrm{H}$ NMR spectra the PdMe protons in both 7 and $7^{\star}$ give rise to two doublets, at $0.82\left({ }^{3} J(\mathrm{P}, \mathrm{H}) 6.7 \mathrm{~Hz}\right)$ and $0.86\left({ }^{3} J(\mathrm{P}, \mathrm{H}) 8.7 \mathrm{~Hz}\right) \mathrm{ppm}$.

Reaction of $\mathrm{PdMe}_{2}[\mathrm{P}-\mathrm{N}]$ with electrophiles

The reactions of dimethylpalladium complexes 7 and $7^{\star}$ with $\mathrm{MeI}, \mathrm{MeBr}$ and $\mathrm{PhCH}_{2} \mathrm{Br}$ (eq. 5 and 6) proceeded rather slowly at room temperature to afford complexes $6 \mathrm{a}, 6 \mathrm{~b}$ and $6 \mathrm{~b}^{\star}$ in $95 \%$ yield after $17 \mathrm{~h}$. In the reaction mixture after treatment of 7 with $\mathrm{MeI}$ and $\mathrm{MeBr}$, ethane was shown to be present by the observation of a singlet in the ${ }^{1} \mathrm{H}$ NMR spectra at $\delta 0.85 \mathrm{ppm}$. Organopalladium(IV) complexes of the type suggested by Stille et al. [8], and made by Canty et al. by use of bipyridine as ligand [9], were not detected in any of these reactions. The ${ }^{1} \mathbf{H}$ NMR spectra of the reaction mixtures showed only signals due to the starting compounds and the products.

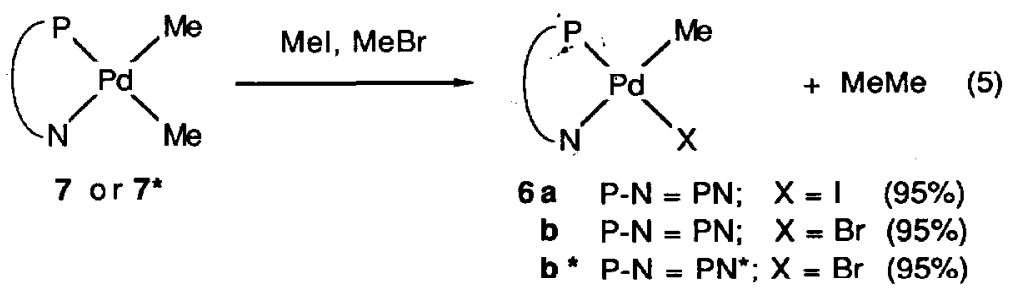

The reaction of $\mathrm{PdMe}_{2}(\mathrm{PN})$ (7) with benzyl bromide (eq. 6) also gave $6 \mathrm{~b}$ in $95 \%$ yield. Use of ${ }^{1} \mathrm{H}$ NMR spectroscopy, GC and GC-MS showed that in this reaction 0.60 equivalent of ethylbenzene and 0.15 equivalent of bibenzyl were formed. A small peak at $0.85 \mathrm{ppm}$ indicated the presence of ethane but the amount was not determined. The presence of the latter two products may be due to a radical process

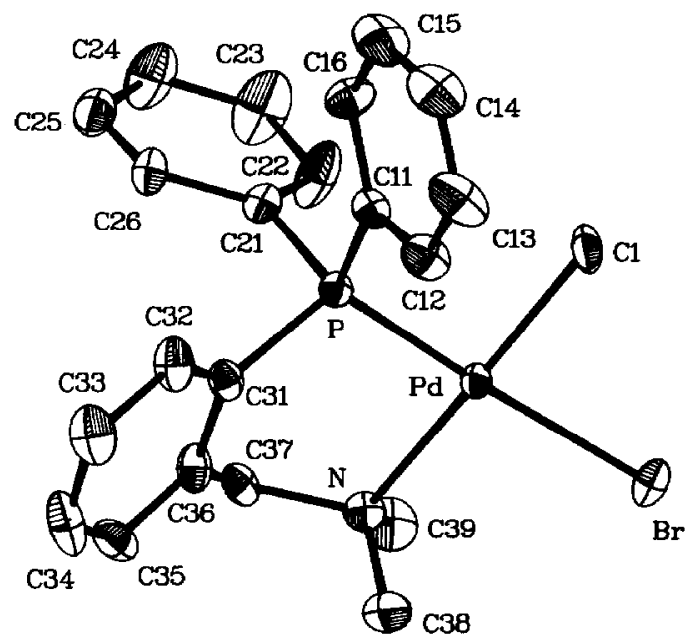

Fig. 1. Molecular structure of $\operatorname{Pd}(\mathrm{Me})(\mathrm{Br})(\mathrm{PN})(6 \mathrm{~b})$ with adopted numbering scheme. 


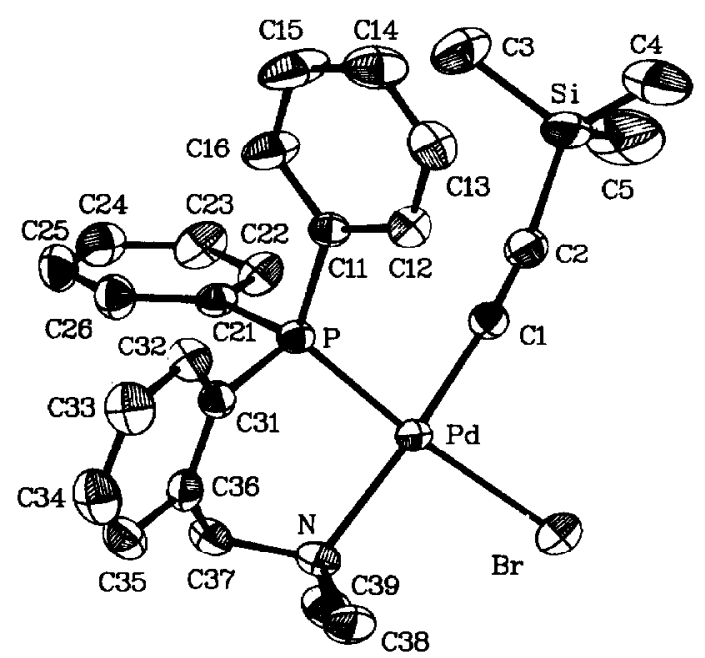

Fig. 2. Molecular structure of $\operatorname{Pd}\left(\mathrm{C} \equiv \mathrm{CSiMe}_{3}\right)(\mathrm{Br})(\mathrm{PN})(6 \mathrm{c})$ with adopted numbering scheme.

or to scrambling of $\mathrm{Me}$ and $\mathrm{PhCH}_{2}$ groups during the reaction.

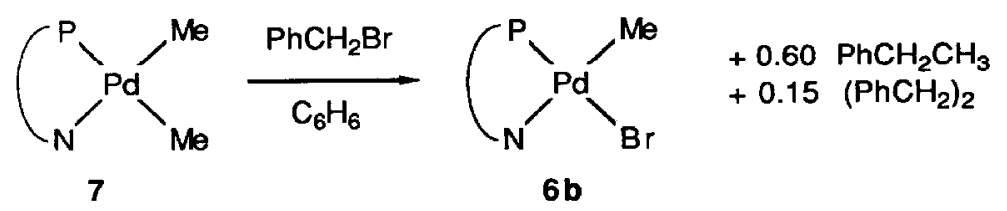

The molecular structures of $\mathrm{Pd}(\mathrm{Me})(\mathrm{Br})(\mathrm{PN})(\mathrm{6b})$ and $\mathrm{Pd}\left(\mathrm{Me} \mathrm{e}_{3} \mathrm{SiC} \equiv \mathrm{C}\right)(\mathrm{Br})(\mathrm{PN})(\boldsymbol{6 c})$

For both compounds the monoclinic unit cells contain 4 equivalent mononuclear units in the form of two pairs of mirror images. The molecular geometry, together with the adopted numbering schemes, are shown in the ORTEP drawings Figs. 1 (6b) and $2(6 c)$. For further crystallographic details see experimental section and Table 2.

Fractional coordinates, selected bond lengths and angles for these complexes are given in Tables 3-6.

In both complexes there is a square planar coordination arrangement around palladium formed by the bidentate ligand, the organic group ( $R$ ), and the bromide in the sequence a- $\mathrm{Br}, \mathrm{b}-\mathrm{R}, \mathrm{c}-\mathrm{P}, \mathrm{d}-\mathrm{N}$. Probably as a result of intramolecular repulsions the planar arrangements are slightly distorted, with twist angles between the planes through $\mathrm{Pd}, \mathrm{Br}, \mathrm{C}(1)$ and through $\mathrm{Pd}, \mathrm{N}, \mathrm{P}$ of $9.2(3)$ and $9.8(2)^{\circ}$ for $\mathbf{6 b}$ and $6 c$, respectively. The angles are comparable to that of $6.8(2)^{\circ}$ in $\mathrm{PdCl}_{2}[(R)-$ ( $S$ )-PPFA] [10].

The six-membered chelate rings, $\mathrm{Pd}-\mathrm{P}-\mathrm{C}(31)-\mathrm{C}(36)-\mathrm{C}(37)-\mathrm{N}$, approach almost ideal boat conformations in both complexes. The aryl rings on phosphorus have a propellor conformation (like that usually found for triphenylphosphine complexes [11]), with inter-ring angles in both complexes close to $90^{\circ}$.

The $\mathrm{Pd}-\mathrm{P}$ and $\mathrm{Pd}-\mathrm{Br}$ distances in both complexes have normal values although the Pd-N distances (2.220(6) $\AA$ for $6 \mathrm{~b}$ and 2.186(3) $\AA$ for $6 \mathrm{c}$ ) are very long (normal range 1.94-2.13 $\AA$ ) [12], reflecting the influence of the strong trans-carbon ligand. 
Table 3

Fractional coordinates for $\mathrm{Pd}(\mathrm{Me})(\mathrm{Br})(\mathrm{P}-\mathrm{N})(\mathrm{Gb})$

\begin{tabular}{|c|c|c|c|}
\hline Atom & $x / a$ & $y / b$ & $z / c$ \\
\hline$\overline{\mathbf{P d}}$ & $0.0000(-)$ & $0.10334(2)$ & $0.5000(-)$ \\
\hline $\mathrm{Br}$ & $-0.1662(1)$ & $0.00377(4)$ & $0.4083(1)$ \\
\hline $\mathbf{P}$ & $0.1710(2)$ & $0.1862(1)$ & $0.5698(1)$ \\
\hline $\mathbf{N}$ & $-0.0549(7)$ & $0.0569(3)$ & $0.6306(4)$ \\
\hline$C(1)$ & $0.029(1)$ & $0.1563(4)$ & $0.3733(5)$ \\
\hline$C(11)$ & $0.3290(8)$ & $0.2121(4)$ & $0.5091(5)$ \\
\hline $\mathrm{C}(12)$ & $0.413(1)$ & $0.1514(5)$ & $0.4788(6)$ \\
\hline$C(13)$ & $0.529(1)$ & $0.1665(6)$ & $0.4295(7)$ \\
\hline$C(14)$ & $0.563(1)$ & $0.2430(6)$ & $0.4097(7)$ \\
\hline$C(15)$ & $0.478(1)$ & $0.3024(6)$ & $0.4374(6)$ \\
\hline$C(16)$ & $0.361(1)$ & $0.2874(4)$ & $0.4878(5)$ \\
\hline$C(21)$ & $0.0864(9)$ & $0.2759(4)$ & $0.6022(5)$ \\
\hline $\mathrm{C}(22)$ & $-0.058(1)$ & $0.2975(6)$ & $0.5571(7)$ \\
\hline$C(23)$ & $-0.127(1)$ & $0.3656(6)$ & $0.5813(9)$ \\
\hline$C(24)$ & $-0.051(1)$ & $0.4104(6)$ & $0.6540(7)$ \\
\hline$C(25)$ & $0.092(1)$ & $0.3875(5)$ & $0.6988(6)$ \\
\hline$C(26)$ & $0.162(1)$ & $0.3224(4)$ & $0.6739(5)$ \\
\hline$C(31)$ & $0.2694(9)$ & $0.1469(4)$ & $0.6781(5)$ \\
\hline$C(32)$ & $0.4298(9)$ & $0.1538(5)$ & $0.7050(5)$ \\
\hline$C(33)$ & $0.503(1)$ & $0.1211(6)$ & $0.7863(7)$ \\
\hline$C(34)$ & $0.416(1)$ & $0.0793(6)$ & $0.8401(6)$ \\
\hline$C(35)$ & $0.258(1)$ & $0.0730(5)$ & $0.8148(5)$ \\
\hline$C(36)$ & $0.1819(9)$ & $0.1070(4)$ & $0.7343(5)$ \\
\hline $\mathrm{C}(37)$ & $0.0091(9)$ & $0.1034(4)$ & $0.7123(4)$ \\
\hline$C(38)$ & $-0.008(1)$ & $-0.0241(4)$ & $0.6460(6)$ \\
\hline$C(39)$ & $-0.228(1)$ & $0.0604(6)$ & $0.6233(7)$ \\
\hline
\end{tabular}

These long Pd-N distances are comparable with those of 2.200(2) and 2.197(2) $\AA$ in $\mathrm{PdMe}_{2}\left(\mathrm{Me}_{2} \mathrm{NCH}_{2} \mathrm{CH}_{2} \mathrm{NMe}_{2}\right)$ [13].

The Pd-C bond length (trans-N) of 2.142(8) $\AA$ in $6 \mathrm{~b}$ is significantly longer than those in other Pd-Me containing complexes, which have been structurally characterized; e.g., 2.026(3) $\AA$ and 2.029(3) $\AA$ in $\mathrm{PdMe}_{2}\left(\mathrm{Me}_{2} \mathrm{NCH}_{2} \mathrm{CH}_{2} \mathrm{NMe}_{2}\right)$ [13], 2.05(2) $\AA$ in trans- $\mathrm{Pd}(\mathrm{Me})\left(\mathrm{OCO}_{2} \mathrm{H}\right)\left(\mathrm{PEt}_{3}\right)_{2}$ [14], and 2.089(3) and 2.090(3) $\AA$ in cis-PdMe ${ }_{2}\left(\mathrm{PMePh}_{2}\right)_{2}$ [15]. Only in $\mathrm{Pd}_{2}(\mathrm{Me})(\mu-\mathrm{I})\left(\mathrm{PPh}_{2} \mathrm{CH}_{2} \mathbf{P P h}_{2}\right)_{2}$ was a longer distance found $(2.27 \AA)$ [16], but in this case there was some disorder between the methyl group and iodine. This is not the case for $\mathbf{6 b}$. The Pd-Me distance does not seem to be in agreement with the trans-influence.

The Pd-C bond length of 1.945(4) $\AA$ in $6 c$ is similar to that found in the only other reported structure of a $\sigma$-ethynyl complex with a trans nitrogen atom, viz. trans- $\mathrm{Pd}\left(o-\mathrm{HC}=\mathrm{CC}_{6} \mathrm{H}_{4} \mathrm{C} \equiv \mathrm{C}\right)(\mathrm{NCS})\left(\mathrm{PPh}_{3}\right)_{2}$, for which it is 1.952(7) $\AA$ [17]. Comparison with trans- $\mathrm{Pd}(\mathrm{C} \equiv \mathrm{CPh}) \mathrm{C}(\mathrm{COOMe})=(\mathrm{HCOOMe})\left(\mathrm{PEt}_{3}\right)_{2}[18]$ and trans$\mathrm{Pd}\left(\mathrm{C} \equiv \mathrm{CSiMe}_{3}\right)(\mathrm{Br})\left(\mathrm{PPh}_{3}\right)_{2}[19]$, in which the corresponding bond lengths are 2.05(2) and $1.974(6) \AA$, respectively, indicates that the amine has a small trans-influence.

The ethynyl group [Pd-C $\left.\equiv \mathrm{CSiMe}_{3}\right]$ in $6 \mathrm{c}$ is slightly distorted from linearity $\left(\mathrm{Pd}-\mathrm{C}(1)-\mathrm{C}(2) 171.7(4)^{\circ}\right.$ and $\left.\mathrm{C}(1)-\mathrm{C}(2)-\mathrm{Si} 172.3(4)^{\circ}\right)$, but, since bending force 
Table 4

Selected bond lengths $(\AA)$ and angles $\left({ }^{\circ}\right)$ for $\operatorname{Pd}(\mathrm{Me})(\mathrm{Br})(\mathrm{P}-\mathrm{N})(\mathrm{b})$

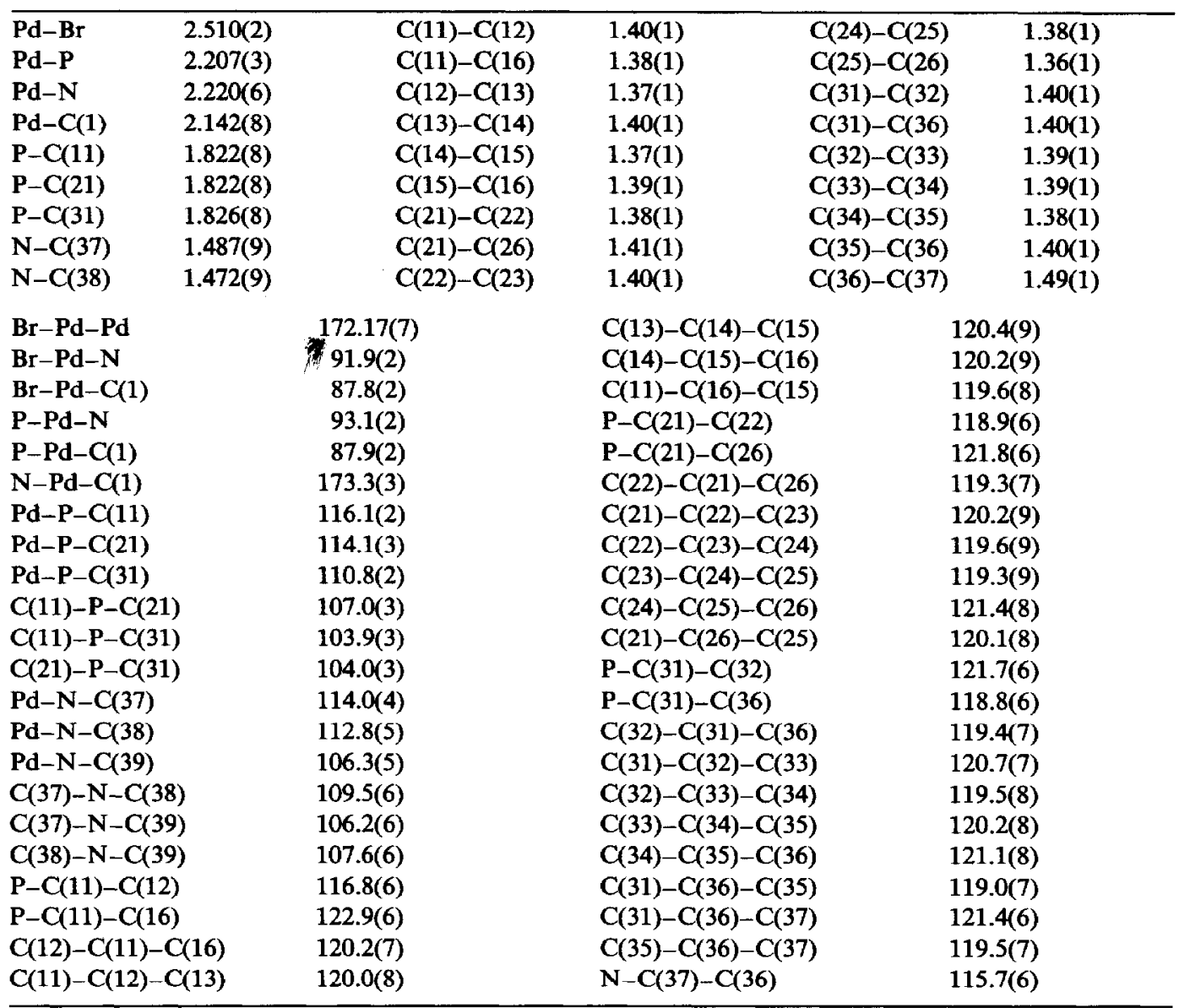

constants of linearly hybridized carbon centres are very small [20], this is probably of steric (vide supra) rather than electronic origin.

\section{Discussion}

\section{Palladium(0) complexes}

The palladium( 0 ) complexes were made by a procedure similar to that used by Coulson for the preparation of $\operatorname{Pd}\left(\mathrm{PPh}_{3}\right)_{4}$ [21]. The fact that washing the compounds with ethanol resulted in their dissolution is in itself indicative of the formation of hydrogen bonds involving free amine sites in the complex.

In general the number of ligands in zerovalent palladium triorganophosphine complexes varies from two to four, depending on their size (cone angle) and electronic properties [22]. In the case of $\operatorname{Pd}(\mathrm{PN})_{3}(4)$ and $\operatorname{Pd}\left(\mathrm{PN}^{\star}\right)_{3}\left(4^{\star}\right)$, it is very likely that the steric hindrance of the free $o-\mathrm{CH}_{2} \mathrm{NMe}_{2}$ or $o-\mathrm{CHMeNMe}$ group prevents the coordination of a fourth ligand. In both complexes exclusive $\mathbf{P d}-\mathbf{P}$ coordination occurs, as was expected since $d^{10}$ palladium $(0)$ tends not to coordinate with $\sigma$-donors, except when extensive back donation, as with phosphines, can take 
Table 5

Fractional coordinates for $\mathrm{Pd}\left(\mathrm{C}=\mathrm{CSiMe}_{3}\right)(\mathrm{Br})(\mathrm{P}-\mathrm{N})(\mathbf{6 c})$

\begin{tabular}{|c|c|c|c|}
\hline Atom & $x / a$ & $y / b$ & $z / c$ \\
\hline Pd & $0.29184(2)$ & $0.92096(3)$ & $0.10655(2)$ \\
\hline $\mathrm{Br}$ & $0.30585(4)$ & $1.08751(5)$ & $0.19757(3)$ \\
\hline $\mathbf{P}$ & $0.2603(1)$ & $0.7800(1)$ & $0.0200(1)$ \\
\hline $\mathrm{Si}$ & $0.1940(1)$ & $1.1949(1)$ & $-0.1025(1)$ \\
\hline $\mathbf{N}$ & $0.3708(2)$ & $0.7899(3)$ & $0.1860(2)$ \\
\hline $\mathrm{C}(1)$ & $0.2410(3)$ & $1.0388(4)$ & $0.0308(2)$ \\
\hline $\mathrm{C}(2)$ & $0.2202(3)$ & $1.1069)(4)$ & $-0.0190(2)$ \\
\hline$C(3)$ & $0.2126(6)$ & $1.0959(6)$ & $-0.1758(3)$ \\
\hline$C(4)$ & $0.0606(5)$ & $1.2497(7)$ & $-0.1227(3)$ \\
\hline$C(5)$ & $0.2793(6)$ & $1.3277(6)$ & $-0.0937(3)$ \\
\hline$C(11)$ & $0.1513(3)$ & $0.7986(4)$ & $-0.0533(2)$ \\
\hline $\mathrm{C}(12)$ & $0.0624(3)$ & $0.8512(4)$ & $-0.0424(2)$ \\
\hline$C(13)$ & $-0.0224(3)$ & $0.8606(4)$ & $-0.0978(3)$ \\
\hline$C(14)$ & $-0.0181(4)$ & $0.8182(5)$ & $-0.1637(3)$ \\
\hline$C(15)$ & $0.0690(4)$ & $0.7627(6)$ & $-0.1752(3)$ \\
\hline$C(16)$ & $0.1539(3)$ & $0.7536(5)$ & $-0.1203(2)$ \\
\hline $\mathrm{C}(21)$ & $0.3679(3)$ & $0.7587(4)$ & $-0.0218(2)$ \\
\hline$C(22)$ & $0.4177(3)$ & $0.8626(4)$ & $-0.0384(2)$ \\
\hline$C(23)$ & $0.5002(3)$ & $0.8481(5)$ & $-0.0705(3)$ \\
\hline $\mathrm{C}(24)$ & $0.5334(3)$ & $0.7350(5)$ & $-0.0842(2)$ \\
\hline $\mathrm{C}(25)$ & $0.4831(4)$ & $0.6324(5)$ & $-0.0694(3)$ \\
\hline$C(26)$ & $0.4009(3)$ & $0.6430(4)$ & $-0.0373(2)$ \\
\hline$C(31)$ & $0.2396(3)$ & $0.6319(4)$ & $0.0591(2)$ \\
\hline$C(32)$ & $0.1573(3)$ & $0.5567(4)$ & $0.0289(2)$ \\
\hline$C(33)$ & $0.1425(4)$ & $0.4450(4)$ & $0.0596(3)$ \\
\hline$C(34)$ & $0.2094(4)$ & $0.4071(5)$ & $0.1200(3)$ \\
\hline$C(35)$ & $0.2902(3)$ & $0.4811(4)$ & $0.1513(2)$ \\
\hline$C(36)$ & $0.3065(3)$ & $0.5945(4)$ & $0.1214(2)$ \\
\hline $\mathrm{C}(37)$ & $0.3971(3)$ & $0.6704(4)$ & $0.1559(2)$ \\
\hline$C(38)$ & $0.4695(3)$ & $0.8476(4)$ & $0.2203(3)$ \\
\hline $\mathrm{C}(39)$ & $0.3116(4)$ & $0.7660(5)$ & $0.2414(2)$ \\
\hline
\end{tabular}

place [23]. Our observation of the absence of $\mathbf{P d}-\mathbf{N}$ coordination is consistent with the structure of $\mathrm{Pd}\left[\mathrm{N}\left(\mathrm{CH}_{2} \mathrm{CH}_{2} \mathrm{PPh}_{2}\right)_{3}\right]$ reported by Orlandini et al., in which there is palladium-amine repulsion [2]. In nickel(0) chemistry, Cullen et al. showed that in the reaction of $\mathrm{Ni}(\mathrm{CO})_{4}$ with $(R)-(S)$-PFFA (2), only one $\mathrm{CO}$ was replaced by this $\mathrm{P}, \mathrm{N}$-bidentate ligand [24]; the new coordinating donor atom was not identified.

\section{Palladium(II) complexes}

In all the new palladium(II) complexes 5-7 with PN or $\mathrm{PN}^{\star}$ as ligand, a well defined 1/1 palladium/ligand ratio was found, and our spectroscopic and crystallographic results show that these ligands form mononuclear square planar $d^{8}$ species with bidentate $\mathbf{P}-\mathbf{N}$ chelate coordination. Similar $\mathbf{P}, \mathbf{N}$-bonding had already been shown in the structures of the $d^{8}$ coordination complexes $\operatorname{PdCl}_{2}[(R)-(S)-\mathrm{PPFA}]$, $\mathrm{PdCl}_{2}$ (o-butylphenylphosphino- $\alpha$-methyl- $N, N$-dimethylbenzylamine) $[10,12]$, and [Rh(cyclooctadiene) $\{(R)-(S)-\mathrm{PPFA}] \mathrm{PF}_{6}[24]$.

Although $\mathrm{Pd}(\mathrm{Me})(\mathrm{Br})(\mathrm{PN})(6 \mathrm{~b})$ can be obtained by three different routes, viz. by oxidative addition of $\mathrm{MeBr}$ to 4, substitution of a bromine atom of the dihalide 
Table 6

Selected bond lengths $(\AA)$ and angles $\left({ }^{\circ}\right)$ for $\mathrm{Pd}\left(\mathrm{C}=\mathrm{CSiMe}_{3}\right)(\mathrm{Br})(\mathrm{P}-\mathrm{N})(6 \mathrm{c})$

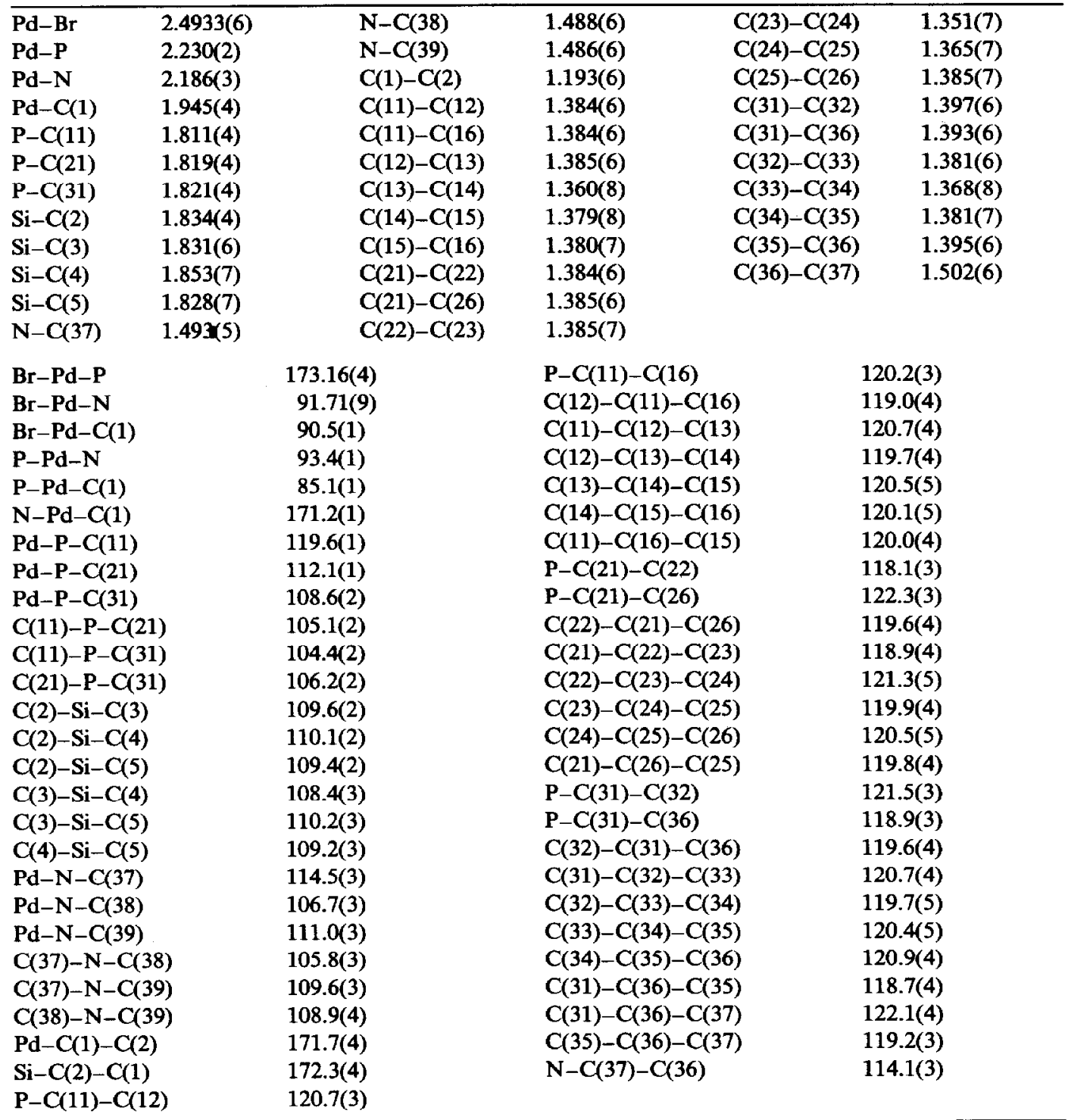

complex 5a, and substitution of a methyl group of dimethyl complex 7 , it is noteworthy that in all cases the product has a geometry with the phosphorus and the carbon atom in a cis-position. Square planar complexes of palladium are much less kinetically stable than those of platinum [7], and it is therefore not clear whether the resulting configuration around palladium in $\mathbf{6 b}$ is kinetically or thermodynamically controlled. In the reaction of $\mathrm{MeLi}$ with $\mathrm{PdBr}_{2}(\mathrm{PN})$ the trans-labilizing effect [7], which is larger for phosphorus than for nitrogen, should result in the incoming methyl group entering trans to phosphorus. However, it is the opposite, thermodynamically controlled, configuration where phosphorus and carbon avoid mutual trans positioning, that is found. This configuration, which is in accord with the 
strong trans influence of these atoms, ensures that competition for the same, $s, d$-hybrid orbital is prevented [25].

\section{Solution stability}

NMR data indicate that in the $\operatorname{Pd}(\mathbf{R})(\mathbf{X})(\mathbf{P}-\mathbf{N})$ complexes the chelating $P, N$ coordination is very stable; complex $6 \mathrm{~b}$ shows no $\mathrm{Pd}-\mathrm{N}$ dissociation even at $65^{\circ} \mathrm{C}$, and moreover, the coordination is not affected by the presence of an excess of free ligand, $\mathrm{CO}$ or $\mathrm{Br}^{-}$, i.e. no ligand exchange or replacement of the nitrogen by phosphorus, $\mathrm{CO}$ or halide occurs. This is in marked contrast to the behaviour of $d^{8}$ $\left[\mathrm{Rh}(\mathrm{PN})_{2}\right] \mathrm{PF}_{6}$, in which the amine functions are reversibly replaced by $\mathrm{CO}$ [26].

The compounds $6 \mathrm{~b}$ and $6 \mathrm{c}$ are the first reported examples of organometallic complexes of type $\mathrm{Pd}(\mathrm{R})(\mathrm{X})(\mathrm{P}-\mathrm{N})$, and are of particular relevance to discussion of metal complex homogeneous catalysis involving chiral ligands. For example, in the cross-coupling reaction of 1-phenylethylmagnesium chloride with vinyl bromide catalyzed by nickel or palladium complexes of ligands 1 or 2 , the high enantioselectivity found has been ascribed to coordination of the ligand's dimethylamino group of the intermediate $\mathrm{Pd}($ vinyl $)(\mathrm{Br})\{(R)-(S)-\mathrm{PPFA}\}$ to the racemic Grignard reagent [1]. In the light of our results on the solution behaviour of $6 b$ and $6 c$, which indicate the presence of an apparently kinetically very stable $\mathrm{P}, \mathrm{N}$-chelate ring, the formation of an intermediate with a free amine function, as proposed by Kumada et al., seems very unlikely.

Another indication of the strength of the P,N-chelate coordination is provided by the stability of the $\mathrm{PdMe}_{2}(\mathrm{P}-\mathrm{N})$ complexes 7 and $7^{\star}$, since reductive elimination from palladium is thought to be preceeded by dissociation of a ligand [27]. It is noteworthy that, contrary to theoretical calculations, even under the conditions of a kinetically inert chelate ring, the presence of a weaker o-donating amine function does not significantly accelerate reductive elimination from $\operatorname{PdMe}_{2}(\mathrm{P}-\mathrm{N})$, relative to that from $\mathrm{PdMe}_{2}\left(\mathrm{Ph}_{2} \mathrm{PCH}_{2} \mathrm{CH}_{2} \mathrm{PPh}_{2}\right)$. This consideration led us recently to the preparation of the remarkably stable $\mathrm{PdMe}_{2}\left(\mathrm{Me}_{2} \mathrm{NCH}_{2} \mathrm{CH}_{2} \mathrm{NMe}_{2}\right)$ [13], which proves that organometallic complexes of palladium do not need stabilisation by ligands having the ability to engage in metal to ligand back-donation.

\section{Reaction with electrophiles}

The reactions of the dimethylpalladium complexes 7 and $7^{\star}$ with electrophiles, which result in slow substitution of one methyl group by a halogen, is significantly different from that of $\mathrm{PdMe}_{2}$ (bipyridine) [10] and $\mathrm{PdMe}_{2}\left(\mathrm{Me}_{2} \mathrm{NCH}_{2} \mathrm{CH}_{2} \mathrm{NMe}_{2}\right)$. In the latter cases the oxidative addition reaction is fast and relatively stable palladium(IV) intermediates can be isolated and/or characterized. However, compared to that of $\mathrm{PdMe}_{2}$ (diphosphines) [9], the reactivities of 7 and $\boldsymbol{7}^{\star}$ are, in spite of the presence of an amine ligand site, not significantly enhanced. We propose that back-donation of palladium to phosphorus reduces the electron density on palladium, and so renders it less reactive towards oxidative addition.

\section{Experimental}

All operations were conducted under dry nitrogen by Schlenk techniques. Solvents were freshly distilled from sodium benzophenone-ketyl. ${ }^{1} \mathrm{H}$ NMR spectra were recorded on a Varian EM 360 and a Bruker AW80 spectrometer and the data are 
given in Table $1 .{ }^{13} \mathrm{C}$ and ${ }^{31} \mathrm{P}$ NMR spectra were recorded on a Bruker WP 200 spectrometer. Elemental analyses were carried out by the Institute of Applied Chemistry (ITC-TNO, Zeist, The Netherlands).

o-Diphenylphosphino- $N, N$-dimethylbenzylamine $(P N, 3)$

This compound was prepared by the procedure described in ref. 8. Yield $50 \%$. B.p. $160-180^{\circ} \mathrm{C} / 0.02 \mathrm{mmHg}$.

(R)-o-Diphenylphosphino- $\alpha$-methyl-N,N,-dimethylbenzylamine $\left(P N^{\star}, 3^{\star}\right)$

This compound was prepared as described in ref. 8 but with t-BuLi in pentane used instead of $\mathrm{n}-\mathrm{BuLi}$ in ether. Yield $77 \%$. B.p. $190-200^{\circ} \mathrm{C} / 0.02 \mathrm{mmHg}$.

Tris(o-diphenylphosphino- $N, N$-dimethylbenzylamine)palladium $\left(P d(P N)_{3}, 4\right)$

This compound was prepared in a manner analagous to that described by Coulson for $\mathrm{Pd}\left(\mathrm{PPh}_{3}\right)_{4}$ [6]. A mixture of $\mathrm{PdCl}_{2}(0.34 \mathrm{~g}, 2$ mmole), PN (3 g, 9 mmole), and DMSO $(50 \mathrm{ml})$ was quickly warmed to $100^{\circ} \mathrm{C}$ with vigorous stirring. To the red homogeneous solution was added $0.5 \mathrm{ml}$ of $\mathrm{NH}_{2} \mathrm{NH}_{2} \cdot \mathrm{H}_{2} \mathrm{O}$, and the mixture was quickly cooled to $20^{\circ} \mathrm{C}$. The precipitate which formed was filtered off and washed with small amounts of THF/diethyl ether $(1 / 1 \mathrm{v} / \mathrm{v})$. The resulting yellow solid product was dried at $100^{\circ} \mathrm{C} / 0.01 \mathrm{mmHg}$. Yield $0.8 \mathrm{~g}(38 \%)$. Found: $\mathrm{C}$, 70.91; H, 6.65; Pd, 10.9, 9.4. $\mathrm{Pd}(\mathrm{PN})_{3}, \mathrm{C}_{63} \mathrm{H}_{66} \mathrm{~N}_{3} \mathrm{P}_{3} \mathrm{Pd}$ calcd.: $\mathrm{C}, 71.08 ; \mathrm{H}, 6.25 ; \mathrm{Pd}$, 9.99\%. cf. $\mathrm{Pd}(\mathrm{PN})_{4}, \mathrm{C}_{84} \mathrm{H}_{88} \mathrm{~N}_{4} \mathrm{P}_{4} \mathrm{Pd}$ : C, 72.90; H, 6.41; Pd, 7.69\%.

Tris [(R)-o-diphenylphosphino- $\alpha$-methyl-N,N-dimethylbenzylamine)] palladium, (Pd$\left.\left(P N^{\star}\right)_{3}, 4^{\star}\right)$

This compound was prepared by a procedure similar to that used for $\operatorname{Pd}(\mathrm{PN})_{3}$ (4). Yield $1.0 \mathrm{~g} \mathrm{(42 \% )}$ of yellow solid. According to its ${ }^{1} \mathrm{H}$ NMR spectrum $4^{\star}$ contained 1.5 to 2 equivalents of dimethyl sulfoxide. Found: C, 72.25; H, 7.07. $\mathrm{C}_{70} \mathrm{H}_{84} \mathrm{~N}_{3} \mathrm{P}_{3} \mathrm{PdO}_{2} \mathrm{~S}_{2}$ calcd.: $\mathrm{C}, 69.03 ; \mathrm{H}, 6.95 \%$.

Variable temperature $N M R$ experiments of $P d\left(P N^{\star}\right)_{3}\left(4^{\star}\right)$

A $10 \mathrm{~mm}$ NMR tube was charged with a solution of $0.3 \mathrm{~g}$ of $\operatorname{Pd}\left(\mathrm{PN}^{\star}\right)_{3}\left(4^{\star}\right)$ in 3 $\mathrm{ml}$ of toluene- $d_{8} ;{ }^{31} \mathrm{P}$ NMR spectra $\left(\mathrm{H}_{3} \mathrm{PO}_{4}\right.$ ext.) were recorded at $30,0,-20$ and $-40^{\circ} \mathrm{C} . \delta\left(-40^{\circ} \mathrm{C}\right)-16.7\left(\mathrm{PN}^{\star}\right)$ and $+17.3 \mathrm{ppm}\left(\operatorname{Pd}\left(\mathrm{PN}^{\star}\right)_{3}\right)$.

${ }^{13} \mathrm{C}$ NMR spectra (TMS int.) were recorded from 20 to $-60^{\circ} \mathrm{C}$ at intervals of $20^{\circ} \mathrm{C} . \delta\left(-60^{\circ} \mathrm{C}\right): \mathrm{PN}^{\star}, 16.34(\mathrm{~s}, \alpha-\mathrm{Me}), 41.32\left(\mathrm{~s}, \mathrm{NMe}_{2}\right)$ and $61.10 \mathrm{ppm}(\mathrm{d}$, $\left.{ }^{3} J(\mathrm{P}, \mathrm{C}) 18.6 \mathrm{~Hz}, C \mathrm{HMe}\right) ; \cdot \operatorname{Pd}\left(\mathrm{PN}^{\star}\right)_{3}, 24.60(\mathrm{~s}, \alpha-\mathrm{Me}), 43.58\left(\mathrm{~s}, \mathrm{NMe}_{2}\right)$ and 62.44 ppm (s, CHMe).

Dichloro(o-diphenylphosphino-N,N-dimethylbenzylamine)palladium $\left(\mathrm{PdCl}_{2}(\mathrm{PN}), \mathbf{5}\right)$

A suspension of $\left[\mathrm{PdCl}_{2}\left(\mathrm{CH}_{3} \mathrm{CN}\right)_{2}\right](0.26 \mathrm{~g}, 1 \mathrm{mmol})$ in $10 \mathrm{ml}$ of benzene was treated with a stoichiometric amount of PN. After overnight stirring the yellow precipitate of 5 was filtered off, washed with pentane, and dried in vacuo. Yields typically $0.47-0.50 \mathrm{~g}(95-100 \%)$. Found: $\mathrm{C}, 51.92 ; \mathrm{H}, 4.61 . \mathrm{C}_{21} \mathrm{H}_{22} \mathrm{Cl}_{2} \mathrm{NPdP}$ calcd.: C, 50.78 ; H. $4.46 \%$.

Dichloro[(R)-o-diphenylphosphino- $\alpha$-methyl-N,N-dimethylbenzylamine]palladium $\left(\mathrm{PdCl}_{2}\left(\mathrm{PN}^{\star}\right), 5^{\star}\right)$

The synthesis of this compound was analogous to that of $\left[\mathrm{PdCl}_{2}(\mathrm{PN})\right](5)$. 
Dibromo(o-diphenylphosphino- $N, N$-dimethylbenzylamine)palladium ([PdBr $2(P N)], 5 a)$

The synthesis of this compound, starting from $\left[\mathrm{PdBr}_{2}\left(\mathrm{CH}_{3} \mathrm{CN}\right)_{2}\right]$, was analogous to that of $\left[\mathrm{PdCl}_{2}(\mathrm{PN})\right]$. No NMR data were obtained owing to the insolubility of this product.

(o-Diphenylphosphino-N,N-dimethylbenzylamine-a-P,b-N)-c-iodo-d-methylpalladium $([P d(M e)(I)(P N)], 6 a)$

$\left[\mathrm{Pd}(\mathrm{PN})_{3}\right](1.0 \mathrm{~g}, 0.94 \mathrm{mmole})$ in $40 \mathrm{ml}$ of benzene was treated with an excess of MeI. The volatiles were removed under reduced pressure and the residue was washed with pentane and dried in vacuo, to afford an air stable pale yellow product $(0.4 \mathrm{~g}, 80 \%)$.

a-Bromo(o-diphenylphosphino- $N, N$-dimethylbenzylamine-c-P,b-N)-d-(trimethylsilylethynyl)palladium ([Pd(Br)(C三CSiMe 3$)(P N)], 6 c)$

The preparation of this compound was similar to that of 6a. The product is an air-stable white solid. Found: $\mathrm{C}, 50.99 ; \mathrm{H}, 4.96$; $\mathrm{Br}, 13.57 . \mathrm{C}_{26} \mathrm{H}_{31} \mathrm{BrNPdPSi}$ calcd.: C, 51.79; H, 5.18: Br, 13.25\%.

a-Bromo $[(R)$-o-diphenylphosphino- $\alpha$-methyl-N,N-dimethylbenzylamine-c-P,b-N]-d(trimethylsilylethynyl)palladium $\left(\left[\mathrm{Pd}(\mathrm{Br})\left(\mathrm{C} \equiv \mathrm{CSiM} \mathrm{e}_{3}\right)\left(\mathrm{PN}^{\star}\right)\right], \mathrm{Gc}^{\star}\right)$

The preparation of this compound was similar to that of $6 \mathbf{a}$. The product is an air-stable white solid.

Reaction of $4^{\star}$ with $\mathrm{Me}_{3} \mathrm{Si} \equiv \mathrm{CBr}$ followed by ${ }^{\prime} \mathrm{H} \mathrm{NMR}$ spectroscopy

A $5 \mathrm{~mm}$ NMR tube was charged with a solution of $50 \mathrm{mg}$ of $\operatorname{Pd}\left(\mathrm{PN}^{\star}\right)_{3}\left(4^{\star}\right)$ in benzene- $d_{6}$ and $0.1 \mathrm{ml}$ of $\mathrm{Me}_{3} \mathrm{SiC} \equiv \mathrm{CBr}$ was added. The ${ }^{1} \mathrm{H}$ NMR spectrum at room temperature showed signals from $6 c^{\star}$ and $\mathrm{PN}$ in a 1/2.0-2.3 molar ratio.

Dimethyl(o-diphenylphosphino-N,N-dimethylbenzylamine)palladium, ([PdMe $\left.\left.e_{2}(P N)\right], 7\right)$

An excess of $\mathrm{MeLi} \cdot \mathrm{LiI}$ was added to a suspension of $0.5 \mathrm{~g}$ of $\left[\mathrm{PdCl}_{2}(\mathrm{PN})\right]$ in diethyl ether at $-78^{\circ} \mathrm{C}$. The mixture was allowed to warm slowly to room temperature and a clear solution was obtained. The solution was shaken at $0^{\circ} \mathrm{C}$ with degassed water, dried over $\mathrm{Na}_{2} \mathrm{SO}_{4}$, and evaporated to dryness. The residue was recrystallized twice from ether/pentane to give cream-coloured crystals of 7 . Yield $0.2 \mathrm{~g}, 40 \%$.

Dimethyl[(R)-o-diphenylphosphino- $\alpha$-methyl-N,N-dimethylbenzylamineJpalladium $\left(\left[P d M e_{2}\left(P N^{\star}\right)\right], 7^{\star}\right)$

The preparation of this compound was similar to that of 7 . Yield $35-40 \%$.

a-Bromo(o-diphenylphosphino- $N, N$-dimethylbenzylamine-c-P,b-N)-d-methylpalladium, $([\mathrm{Pd}(\mathrm{Br})(\mathrm{Me})(\mathrm{PN})], \mathrm{6b})$

An excess of either $\mathrm{MeBr}$ or $\mathrm{PhCH}_{2} \mathrm{Br}$ was added to a solution of [PdMe $(\mathrm{PN})$ ] $(0.75 \mathrm{~g}, 1.70 \mathrm{mmol})$ in $30 \mathrm{ml}$ of benzene. After overnight standing pale yellow crystals of $\mathbf{6 b}$ were formed. The solution was decanted off and the precipitate washed with pentane and dried in vacuo. Yield $0.80 \mathrm{~g}, 95 \%$. Found: $\mathrm{C}, 48.95 ; \mathrm{H}$, 4.79; $\mathrm{Br}, 15.64$. $\mathrm{C}_{22} \mathrm{H}_{25} \mathrm{BrNPdP}$ calcd.: $\mathrm{C}, 49.79 ; \mathrm{H}, 4.58 ; \mathrm{Br}, 15.78 \%$.

Ethylbenzene and bibenzyl were identified in the mother liquor by ${ }^{1} \mathbf{H}$ NMR spectroscopy and GC-MS analysis (EtPh: $M^{+}=106.91 ; \mathrm{PhCH}_{2} \mathrm{CH}_{2} \mathrm{Ph}: M^{+}=$ 
182.91). GC analysis with decane as internal standard showed the presence of 0.60 equivalents of ethylbenzene and 0.15 equivalents of bibenzyl.

a-Bromo[(R)-o-diphenylphosphino- $\alpha$-methyl-N,N-dimethylbenzylamine-c-P,b-N]-dmethylpalladium ( $\left.\left[\mathrm{Pd}(\mathrm{Br}) \mathrm{Me}\left(\mathrm{PN}^{\star}\right)\right], \mathrm{6b}^{\star}\right)$

The preparation of this compound was similar to that of $6 \mathrm{~b}$ but diethyl ether was used as solvent. $\mathbf{6 b}^{\star}$ was obtained as white powder. Yield $92 \%$.

\section{${ }^{1} \mathrm{H} N M R$ studies of $\left[\mathrm{Pd}(\mathrm{Me})(\mathrm{Br})\left(P N^{\star}\right)\right]\left(6^{\star}\right)$}

A $5 \mathrm{~mm}$ NMR tube was charged with $50 \mathrm{mg}$ of $6 \mathrm{~b}^{\star}$ in $0.5 \mathrm{ml}$ of $\mathrm{CDCl}_{3} \cdot{ }^{1} \mathbf{H}$ NMR spectra were recorded from -53 to $+67^{\circ} \mathrm{C}$. No coalescence or significant change in chemical shifts was observed. The breadth of the NMe signals generally decreased with increase of temperature.

A new sample was prepared and CO was bubbled through for $0.5 \mathrm{~h}$, after which the ${ }^{1}$ H NMR spectrum was recorded, and found to be identical with the original spectrum.

A new sample was prepared and $\mathrm{Bu}{ }_{4} \mathrm{NBr}$ was added. The ${ }^{1} \mathrm{H} \mathrm{NMR}$ spectrum was recorded and showed the spectra of both compounds separately.

Reaction of dibromo[o-diphenylphosphino-N,N-dimethylbenzylamine]palladium (5a) with one equivalent of $\mathrm{MeLi}$

A suspension of finely-powdered $\left[\mathrm{PdBr}_{2}(\mathrm{PN})\right](0.35 \mathrm{~g}, 0.5 \mathrm{mmol})$ in $10 \mathrm{ml}$ of diethyl ether was cooled to $-60^{\circ} \mathrm{C}$ with stirring, and $0.5 \mathrm{ml}$ of a solution of MeLi $\cdot \operatorname{LiBr}(1 M)$ in diethyl ether was added. The mixture was allowed to warm to room temperature. Stirring was continued for $15 \mathrm{~min}$ and then $5 \mathrm{ml}$ of degassed water was added and the organic layer separated. The aqueous suspension was washed with $5 \mathrm{ml}$ of diethyl ether and the combined organic layers evaporated to leave $\left[\mathrm{PdMe}_{2}(\mathrm{PN})\right](\mathbf{5 a})(0.15 \mathrm{~g}, 45 \%)$ as cream-coloured crystals. Further extraction of the final aqueous suspension with $1 \mathrm{ml}$ of $\mathrm{CDCl}_{3}$ provided an extract whose NMR spectrum showed the presence mainly of starting compound and about $10 \%$ (relative to the starting compound) of $[\mathrm{Pd}(\mathrm{Br}) \mathrm{Me}(\mathrm{PN})] .{ }^{1} \mathrm{H} \mathrm{NMR}\left(\mathrm{CDCl}_{3}\right): \delta 0.65$ (d, $\left.{ }^{3} J(\mathrm{P}, \mathrm{H}) 3.7 \mathrm{~Hz}, \mathrm{Me}\right)$.

Crystal structure analysis for a-bromo(o-diphenylphosphino- $N, N$-dimethylbenzylamine$c-P, b-N)$-d-methylpalladium, ([Pd(Br)(Me)(PN)], $6 b)$

Crystal data and data collection information are given in Table 2. X-ray quality crystals were obtained from a dichloromethane solution by hexane vapour diffusion. An orange crystal $(0.2 \times 0.3 \times 0.6 \mathrm{~mm})$ was selected and mounted on an Enraf-Nonius CAD4 diffractometer. Reflections $h k l$ were measured with $0 \leq h \leq 10$, $-21 \leq k \leq 21,-18 \leq l \leq 17$. Four standard reflections (2 2 2: r.m.s.d. 1.10\%; $2-2$ 2: r.m.s.d. $085 \% ; 22-2$ : r.m.s.d. $0.77 \% ; 2-2-2$ : r.m.s.d. $0.65 \%$ ) were measured every 50 reflections and corrections were made for longe range intensity variations. Systematic absences $(h k l, h+k=2 n+1$ and $h 0 l, l=2 n+1)$ indicate space group $C c$ or $C 2 / c$. As the experimental density of $1.568 \mathrm{~g} / \mathrm{cm}^{3}$ (by flotation) limits the number of formula units in the unit cell to four and the molecule has no twofold rotation symmetry, the space group is $C c$. The structure was solved by standard Patterson and Fourier methods (SHELX 76) [28]. An empirical absorption correction was applied before anisotropic refinement with the program DIFABS [28] 
(absorption factors: min. 0.78 and max. 1.52). Hydrogen atoms were placed at calculated $\mathrm{C}\left(s p^{3}\right)$ and $\mathrm{C}\left(s p^{2}\right)$ positions at a distance of $1.08 \AA$, and were refined riding on their carrier atoms with a general isotropic thermal parameter. Anisotropic refinement of the positions of the non-hydrogen atoms converged to $R(F)=0.042$. The polarity of the structure was tested by refinement with $+i f^{\prime \prime}$ and $-i f^{\prime \prime}$ values. With -if" the structure converged to $R(F)=0.031$ and therefore subsequent refinements were carried out for the inverted structure. The final model with 51 atoms and 234 parameters refined to $R(F)=0.030$ and $R(w F)=0.036$ with $w=1 / \sigma^{2}\left(F_{0}\right)$.

Crystal structure analysis for a-bromo(o-diphenylphosphino-N,N-dimethylbenzylamine$c-P, b-N)-d-\left(\right.$ trimethylsilylethynyl)palladium, $\left(\left[\mathrm{Pd}(\mathrm{Br}) \mathrm{C} \equiv \mathrm{CSiMe}_{3}(\mathrm{PN})\right], 6 \mathrm{c}\right)$

Crystal data and data collection information are given in Table 3. X-ray quality crystals were obtained from a dichloromethane solution by hexane vapour diffusion. An orange crystal $(0.2 \times 0.5 \times 0.5 \mathrm{~mm})$ was selected and mounted on an Enraf-Nonius CAD4 diffractometer. Reflections $h k l$ were measured with $0 \leq h \leq 17$, $0 \leq k \leq 13,-24 \leq l \leq 24$. Three standard reflections (4 0 0: r.m.s.d. 1.7\%; 040 : r.m.s.d. $0.79 \%$; 004 ; r.m.s.d. $0.93 \%$ ) were measured every 50 reflections and corrections were made for longe range intensity variations. A correction for the effects of absorption was derived from the intensity variations of the 040 reflection, which was measured as a function of $\Psi$. This intensity variation was used to refine the distances between the seven crystal faces describing the crystal. Absorption coefficients for every reflection were calculated on the basis of the refined crystal model with the program ABSORB [30] (absorptionfactors: min. 1.25 and max. 1.86). The structure was solved by standard Patterson and Fourier methods (SHELX 76) [27]. Hydrogen atoms were placed at calculated $\mathrm{C}\left(s p^{3}\right)$ and $\mathrm{C}\left(s p^{2}\right)$ positions at a distance of $1.08 \AA$, and were refined riding on their carrier atoms with a general isotropic thermal parameter. The final model with 62 atoms and 281 parameters refined to $R(F)=0.038$ and $R(w F)=0.034$ with $w=1 / \sigma^{2}$ $\left(F_{0}\right)$.

For both structure determinations, scattering factors and anomalous dispersion corrections were taken from the 'International Tables of X-ray Crystallography' [31]. Calculations were performed with SHELX 76 [28] (structure determination and refinement), DIFABS [29], ABSORB [30] (absorption corrections), the EUCLID [32] package (molecular geometry) and ORTEP [33] (illustrations) on the CDC Cyber 180-185 of the University of Utrecht.

\section{References}

1 M. Kumada, Pure \& Appl. Chem., 52 (1980) 669; T. Hayashi and M. Kumada, Acc. Chem. Res., 15 (1982) 395; T. Hayashi and M. Kumada, Asymmetric Synthesis, Vol. 5, Academic Press, London, 1985, Ch. 5 , p. 147.

2 C.A. Ghilardi, S. Midollini, S. Monetti, and A. Orlandini, J. Chem. Soc., Chem. Commun., (1986) 1771.

3 S.E. Livingstone, in Vol. 4, A.F. Trotman-Dickenson (Ed.) Comprehensive Inorganic Chemistry, Pergamon Press, 1973, p. 1304.

4 T.G. Appleton and H.C. Clark, Coord. Chem. Rev., 10 (1973) 335; W.L. Steffen and G.J. Palenik, Inorg. Chem., 15 (1976) 2432.

5 T.H. Rauchfuss, F.T. Patino and D.M. Roundhill, Inorg. Chem., 14 (1975) 652. 
6 G.Calvin and G.E. Coates, J. Chem. Soc., (1960) 2008.

7 F. Basolo, Mechanisms of Inorganic Reactions, in Adv. in Chem. Series, 49 (1965) 90.

8 D. Milstein and J.K. Stille, J. Am. Chem. Soc., 101 (1979) 4994; A. Moravskiy and J.K. Stille, ibid., 103 (1981) 4182.

9 P.K. Byers, A.J. Canty, B.W. Skelton and A.H. White, J. Chem. Soc., Chem. Commun., (1986) 1722.

10 F.H. van der Steen and J.A. Kanters, Acta Cryst. C, 42 (1986) 547.

11 K. Mislow, Acc. Chem. Res., 9 (1976) 26.

12 A. Tanaka, Y. Sasada, K. Yamamoto and J. Tsuji, Bull. Chem. Soc. Jpn., 50 (1977) 3177.

13 W. de Graaf, J. Boersma, D.M. Grove, A.L. Spek and G. van Koten, Recl. Trav. Chim. Pays-Bas, 107 (1988) 299.

14 J.M. Wisner, T.J. Bartczak, and J.A. Ibers, Organometallics, 5 (1986) 2044.

15 R.J. Crutchley, J. Powell, R. Faggiani, and C.J.L. Lock, Inorg. Chim. Acta, 24 (1977) L15.

16 M.M. Olmstead, J.P. Farr, and A.L. Balch, Inorg. Chim. Acta, 52 (1981) 47.

17 U. Behrens and N.K. Hoffmann, J. Organomet. Chem., 129 (1977) 273.

18 T. Yasuda, Y. Kai, N. Yasuoka, and N. Kasai, Bull. Chem. Soc. Jpn., 50 (1977) 2888.

19 E. van de Voort, A.L. Spek, and W. de Graaf, Acta Cryst. C, 43 (1987) 2311.

20 E.B. Wilson, J.C. Decius and P.C. Cross, Molecular Vibrations, McGraw-Hill, New York, 1955, p. 176.

21 D.R. Coulson, Inorg. Synth., 13 (1972) 121.

22 W. Kuran and A. Musco, Inorg. Chim. Acta, 12 (1975) 187.

23 P.M. Maitlis, The Organic Chemistry of Palladium, Vol. I, Academic Press, London, 1971, p. 8.

24 W.R. Cullen, F.B.W. Einstein, C.-H. Huang, A.C. Willis, and E.-Shan Yeh, J. Am. Chem. Soc., 102 . (1980) 988.

25 S.Z. Zumdahl and R.S. Drago, J. Am. Chem. Soc., 90 (1968) 6669.

26 T. Rauchfuss and D.M. Roundhill, J. Organomet. Chem., 69 (1973) C30.

27 A. Gillie and J.K. Stille, J. Am. Chem. Soc., 102 (1980) 4933; F. Ozawa, T. Ito, Y. Nakamura and A. Yamamoto, Bull. Chem. Soc. Jpn., 54 (1981) 1886; K. Tatsumi, R. Hoffmann, A. Yamamoto, and J.K. Stille, ibid., 54 (1981) 1857.

28 G.M. Sheldrick, Program for crystal structure determination, Univ. of Cambridge, England, 1976.

29 N. Walker, J.T. Steward, Acta Cryst. A, 39 (1983) 158.

30 A.L. Spek, ECM8 Abstract Book p. 283, 1983.

31 D.T. Cromer and J.T. Waber, International Tables for X-ray Crystallography, Kynoch Press, Birmingham, England, 1974.

32 A.L. Spek, in D. Sayre (Ed.), The EUCLID Package in ' Computational Crystallography', p. 582, 1982, Oxford, Clarendon Press.

33 C.K. Johnson, ORTEP, Report ORNL-5138. Oak Ridge, National Laboratory, Tennesee. 